\title{
Correction to: Clinical relevance of the tumor microenvironment and immune escape of oral squamous cell carcinoma
}

\author{
Alexander W. Eckert ${ }^{1 * \dagger}$, Claudia Wickenhauser ${ }^{2 \dagger}$, Paul C. Salins ${ }^{3}$, Matthias Kappler ${ }^{1 \dagger}$, Juergen Bukur ${ }^{4}$ \\ and Barbara Seliger ${ }^{4^{*}+}$
}

\section{Correction to: J TransI Med (2016) 14:85} https://doi.org/10.1186/s12967-016-0828-6

The original version of this article [1], published on 5 April 2016, contains a mistake. In the 'Role of $\mathrm{pH}$ stabilisation' section, "intracellular $\mathrm{pH}$ " has been incorrectly abbreviated as "pHe". The correct abbreviation is "pHi". The affected sentence with the correct abbreviation is given below.

- The metabolic adaption accumulates different ionic exchangers at the tumor cell membrane to maintain intracellular pH (pHi) (Fig. 2).

The figure which is cited in the above sentence can be reviewed in the original article.

\section{Author details}

${ }^{1}$ Department of Oral and Maxillofacial Plastic Surgery, Martin-Luther-University Halle-Wittenberg, Ernst-Grube-Str. 40, 06120 Halle (Saale), Germany. ${ }^{2}$ Institute of Pathology, Martin-Luther-University Halle-Wittenberg, Magdeburger Str. 8, 06110 Halle (Saale), Germany. ${ }^{3}$ Mazumdar Shaw Cancer Center and Narayana Hrudayalaya Multi Specialty Hospital, 258/A, Bommasandra Industrial Area, Bangalore 560099, India. ${ }^{4}$ Institute of Medical Immunology, Martin-Luther-University Halle-Wittenberg, Magdeburger Str. 2, 06110 Halle (Saale), Germany.
The original article can be found online at https://doi.org/10.1186/ s12967-016-0828-6.

\section{Publisher's Note}

Springer Nature remains neutral with regard to jurisdictional claims in published maps and institutional affiliations.

Received: 2 February 2018 Accepted: 2 February 2018

Published online: 28 February 2018

\section{Reference}

1. Eckert AW, Wickenhauser C, Salins PC, Kappler M, Bukur J, Seliger B. Clinical relevance of the tumor microenvironment and immune escape of oral squamous cell carcinoma. J Transl Med. 2016;14:85. https://doi. org/10.1186/s12967-016-0828-6.

\footnotetext{
*Correspondence: aw.eckert.wissenschaft@web.de; barbara. seliger@uk-halle.de

${ }^{\dagger}$ Alexander W. Eckert, Claudia Wickenhauser, Matthias Kappler and Barbara Seliger contributed equally to the manuscript

1 Department of Oral and Maxillofacial Plastic Surgery, Martin-LutherUniversity Halle-Wittenberg, Ernst-Grube-Str. 40, 06120 Halle (Saale), Germany

${ }^{4}$ Institute of Medical Immunology, Martin-Luther-University HalleWittenberg, Magdeburger Str. 2, 06110 Halle (Saale), Germany Full list of author information is available at the end of the article
} provided you give appropriate credit to the original author(s) and the source, provide a link to the Creative Commons license, and indicate if changes were made. The Creative Commons Public Domain Dedication waiver (http://creativecommons.org/ publicdomain/zero/1.0/) applies to the data made available in this article, unless otherwise stated. 